\title{
A SAD STORY, IN SPITE OF ITS HAPPY ENDING A REVIEW OF ANAK AGUNG'S BOOK
}

by Mohamad Roem

"A sad story, in spite of its happy ending"--such was the conclusion of Lester Pearson, Canada's former Prime Minister and former Minister of Foreign Affairs, in his foreword to the book: Indonesian Independence and the United Nations, by Alastair M. Taylor (Ithaca, N.Y.: Cornell University Press, 1960), p. xvi. Then Lester Pearson gave the following picture:

It is not surprising, therefore, that negotiations were long and bitter and filled with delays and obstructions. Events, however, worked progressively for the Indonesians and against the Dutch, in part through the skill with which the former advanced their case at the United Nations. It was this compulsion of events, as well as the force of public opinion, especially in Asia, and expressed at the United Nations, which finally brought the Dutch Government to the realization that its diplomatic and negotiating position was not as strong as it was thought to be. Moreover, it was getting weaker, as certain actions of the Netherlands, such as the breaking of the truce in December 1948 , forfeited the possibility of active support from its North Atlantic friends. This deterioration in the diplomatic position was a bitter disappointment to the Dutch, but it made a solution possible. The Dutch, after all, unlike their bitterest critic on the Security Council, the U.S.S.R., were not the kind of people to pursue a quarrel of this kind to its ultimate and brutal conclusion by fire and sword--especially as they were already committed to the objective of an independent Indonesia. ( $p$. xiii)

"That sad story" I read again in Anak Agung's book, this time not merely as a summary in a foreword, but in a dissertation that takes up 403 pages, entitled "Renville as the Turning Point in the Indonesian-Dutch Negotiations, a Dissertation for the degree of Doctor of Letters at the State University of Utrecht, on the authority of rector magnificus Prof. Dr. A. Verhoeff, based on the decision of the Faculty Council, publicly defended on Thursday, May 2, 1980." The sad story is related from its very beginning, in detail, in a scholarly manner, with full citations drawn from official documents, as is required for a scholarly work.

And maybe because the title of this dissertation is "Renville as the Turning Point," Anak Agung begins with the period before the negotiations, in fact at a time when Indonesia was still colonized by the Dutch, i.e., with the Ethical Policy, pursued by the Dutch as a new policy for the twentieth century (Introduction, pp. 11-12). Then Anak Agung gives a summary of the Indonesian-Dutch negotiations prior to the Renville Agreements (Chapter 1, pp. 24-25). The Renville Agreement, the difficulties that arose after it was signed, Foreign Minister Stikker's Mission to Yogya to talk with Hatta, in which it was said Hatta withdrew promises formerly given, which became the reason for the Dutch to launch their second military action, take up pp. 55-195, with the exception of a chapter concerning the federal territories. 
Actually, by this point the title of the book has been fulfilled; but Anak Agung continues his exertions up to the discussions on the Indonesian dispute in the Se-: curity Council concerning the second military action. The book ends with the transfer of sovereignty on December 27, 1949, in the two places, Amsterdam and Jakarta, at the same moment.

So Anak Agung narrates the whole period of negotiations and their implementation. The Indonesian dispute is discussed thoroughly, according to the most exacting standards, i.e., in a dissertation. The problem of West Irian remained. But despite the intractability of this issue, there is sufficient reason to say that, with the transfer of sovereignty on December 27, 1949, the Indonesian dispute came to an end.

\section{An Indonesian Creation}

Dr. T. B. Simatupang once wrote: "We must recognize that we do not yet possess historical works created by Indonesian writers concerning our people's strug-. gle for independence that approach the requisite quality. (See Mohamad Roem 70 Tahun, under the title "Historical Writing on the Indonesian People's Struggle for Independence," p. 293.) The Indonesian people's struggle for independence did not begin with the Proclamation. However, the Indonesian-Dutch negotiations, that began in 1945 and ended with the transfer of sovereignty on December 27, 1949, form a very important part. On this dimension, then, in my opinion, this dissertation of Anak Agung approaches the requisite standard. This is a weighty book that enriches the library on the history of the Indonesian people.

It is understandable that he writes in Dutch. If someone wishes to write a serious history of that time, it is difficult not to think of looking first at what can be read in The Netherlands, England, Washington, and in the United Nations Library, because from the beginning the English and the U.N. Committee of Good Offices participated in the Indonesian-Dutch negotiations. The most incomplete materials are in Indonesia, because of the moving of the Republican capital during the guerrilla war, and of various active participants from one place to another, and in and out of Dutch hands, so that they could not save their records. The most complete are in The Netherlands, which has preserved all official and formal documents from the negotiations.

Because the archives in The Netherlands concerning the Dutch-Indonesian negotiations are complete, for Anak Agung, who belongs to "the vanishing race" of people who still know Dutch, the practical step then was to work close to those archives and at the same time write his dissertation. Anak Agung was also able to read stillsecret documents in the Ministry of Overseas Territories and Foreign Affairs. The Netherlands is an open state. There is a brief period of 25 years during which certain documents must be kept secret; after that there are no longer any secrets. Reading this dissertation of Agung, I encountered passages from documents that are still "secret," but have become public after being dealt with in Agung's book.

\section{Several Weaknesses}

I can express praise and recommend this work of Agung with a sincere heart. In that spirit I wish to point to several weaknesses. The documents found in those Dutch archives, even though they do not deviate in the slightest from the official documents regarding proposals and counterproposals--in these matters the Dutch are well known for their honesty--yet in their view and way of thinking the Dutch are different from the Indonesians. On occasion the Dutch view or way of thinking has found its way into Anak Agung's book. Up to Anak Agung's motion of March 3, 
1949 , the BFO (Bijeenkomst voor Federaal Overleg) was still cooperating with the Dutch. Only after that did the BFO form a common front in confronting the Dutch until the end of the Round Table Conference. The Dutch were very unhappy with this development.

Chapter II, entitled "The Renville Agreement," begins thus: "The Renville Agreement can be viewed as the decisive turning point in the Indonesian-Dutch negotiations." As an explanation, Anak Agung suggests that from the beginning the Dutch viewed the Indonesian problem as an internal problem, while Renville transformed the Indonesian problem into one of intensive involvement by the UN. Without denying this, it must be pointed out that Linggajati also had involved the international world in the Indonesian dispute. Not yet as clearly as with the Committee of Good Offices which was formed by the UN, but it must not be forgotten, for example, that the ceasefire signed on October 14, 1946, was an agreement between the Forces of the Republic of Indonesia on the one hand, and the Allies on the other, made up of the Dutch and the English.

The gradual increase in international involvement could no longer be obstructed by the Dutch.

\section{The Low Point}

Renville, in my opinion, can be viewed as the low point, "dieptepunt;" for the Republic of Indonesia. I thought at the time that the Dutch felt they had gained a great victory. The Dutch were not condemned because of their first aggression, but rather, through Renville, what they had achieved was legalized. By diplomacy, Renville legalized the Van Mook Line, so that the Republic abandoned territory it still controlled, where the Republican agencies, such as the pamong praja, education, health, and so on, still operated. In those areas the Republican guerrillas were also still active. Those areas were inhabited by 25 million people. Through diplomatic means Dutch power entered that area. As many as 35,000 of our soldiers with their weapons withdrew [hijrah] to Republican territory, under Good Offices Committee supervision.

That Renville was the "low point" for the Republic is not necessarily in contradiction with the judgment that the Agreement was reached with UN involvement in the form of the Committee of Good Offices. That "low point" can be understood if we follow the political developments in the Republic. The PNI withdrew from the Amir cabinet because it did not agree with Renville; Masjumi, which had only entered the Amir cabinet after the first military action, also withdrew, giving the same reason. Because Renville had become a state undertaking that had to be respected, these two parties asked for the State to be led by a strong man. Accordingly, Bung Karno appointed Hatta as formateur. As Renville was so damaging,it had to be implemented in such a way that the Republic not deteriorate further.

In connection with this situation, Anak Agung writes on p. 85, "In order to overcome the confusing (chaotic) political situation, and as a result of pressure from the Masjumi party, President Sukarno charged Vice President Hatta with forming a Cabinet." I think that in this matter Anak Agung has slipped, and is using Dutch spectacles. The Dutch often and with glee at that time portrayed the Republic as always being in a chaotic situation, unable to control its armed forces, and so on. The political situation in the Republic was not confused (chaotic). The PNI and Masjumi withdrew from the cabinet for legitimate political reasons. They wanted the substitution of a strong cabinet. Sukarno asked Hatta to form such a cabinet.

All this took place according to the "rules of the game" in a respected parliamentary democracy. 


\section{A Negative Evaluation}

On the same page, we read: "Because Hatta was one of the Proclaimers of the independence of the Republic, and a prominent leader in the nationalist movement, then it could actually be hoped that there would be sufficient authority from this cabinet to conduct the negotiations that were about to begin. On the other hand, it must be suggested that Hatta was a principled nationalist, for whom it would be difficult to make compromises, if they concerned the national interest."

In the first sentence a negative evaluation of Hatta is inserted. The second sentence is not true. Hatta was indeed a principled nationalist. However, Hatta was certainly not known as a negotiator who found it difficult to make compromises. In the KMB, Hatta was more flexible than Dr. Soemitro and Roem on the question of the formation of a commission to decide how much in debts was to be taken over by Indonesia. On the matter of West Irian Hatta was more flexible than Anak Agung. Those two sentences try to show that, if the negotiations were not smooth, then Hatta was at fault. In fact, at that time, the Dutch were stalling for time and were not serious about reaching an agreement.

In this book of Anak Agung one instruction to the Dutch Delegation is mentioned that proves the intention to deadlock the negotiations. The Dutch demanded that the Republic dissolve its Foreign Relations, abolish its rupiah currency, and dissolve the Armed Forces. On these matters, it was clear that the Republic could not and would not agree. These demands were not in accord with the private understanding of the individual members of the Committee of Good Offices.

Concerning the Linggajati agreement, Anak Agung writes on p. 38, "This meant that the Linggajati Agreement, that had been emended thanks to the intervention of Sukarno, had not got the agreement of the Republic's Guardian of Highest Authority." Once again Anak Agung is wearing Dutch spectacles. Sukarno and Hatta did not emend and did not intervene. It is difficult to imagine Sjahrir, Prime Minister of a parliamentary cabinet, or indeed members of the delegation, including me, accepting Sukarno's intervention. Sukarno and Hatta also never felt they were "emending" or intervening.

That was the game played by Van Mook, with which the Commission-General fell in, when they met with Sukarno-Hatta in Kabupaten Kuningan and invited Sukarno-Hatta to talks, and tried to have those talks viewed as negotiations. Van Mook brought copies of his drafts which were then distributed to Sukarno and Hatta. Sukarno, who did not guess Van Mook's hidden intentions, was naturally willing to be invited to talk over these formulations; however, he was completely unaware that these talks would be viewed as negotiations which bypassed the delegation. Sukarno, who at that time completely failed to smell a rat, made this personal comment: "For me, if the word (vrij) is changed to sovereign ("berdaulat") then I'm satisfied." These words were taken over by Van Mook who made every effort to claim that the negotiations were thereby completed. In fact, of course, still outstanding at the very least were Article 17, concerning the possibility of arbitration through the services of the President of the International Court of Justice, and the Republican delegation's amendment to Article 1. The intent of the amendment to Article 1 was for immediate steps to begin for the gradual return of the Republican territories occupied by the Dutch, so that by the time the Federal Republic of Indonesia was born that return could be completed.

Van Niook called this effort a "truc" (a trick); indeed he felt he had triumphed.

However, when this "truc" was pronounced at the plenary session with the knowledge of Lord Killearn, we strongly protested. Professor Schermerhorn said 
"Daar heb je de poppen aan het dansen." (There the uproar began.) With regard to the amendment to Article 1, I had written [it] on "rose paper," and at the order of Prof. Schermerhorn I had given it to the Secretary. Mr. Samkalden said that the above "rose paper" certainly did not exist. As I still knew by heart what I had proposed as an amendment, I repeated it orally. Later, after the session, Samkalden acknowledged to Prof. Schermerhorn that "that rose paper is stored in the archives."

The Indonesian delegation called the affair of these discussions with SukarnoHatta the "Incident at Linggajati." In his diary Prof. Schermerhorn writes fully and correctly in Volume 1, pp. 116, 117, 118, 119, and 120. "Direct hier achteraan moge ik vermelden, dat deze geschiedenis met artikel 1 eigenlijk de enige vlek is, in de stijl van de onderhandelingen.". ("Immediately after this I would like to report that this story of Article 1 is actually the only blot on our style of conducting negotiations.")

After that "intervention" of Sukarno, the delegations continued negotiating at Linggajati; then these were continued in Jakarta before their initialing as if there had been no intervention. It was Amir Sjarifuddin and Adnan Gani who accompanied the Commission-General from Linggajati to Kuningan, while Sjahrir, Soesanto, and Roem remained in Linggajati.

Article 17 of Linggajati was indeed an article that was unacceptable to the Dutch Government. A rule to resolve disputes through the mediation of the President of the International Court of Justice would have meant, for the Dutch, treating the Republic too much as an already-independent state. Paragraph 1 meant that the gradual return of areas occupied by the Dutch within Republican territory had to begin immediately. However, just the opposite happened. One day after Linggajati was initialed Mojokerto was attacked, then Bogor and Palembang, and other regions.

\section{Several Incidents}

When the Dutch delegation came to Cirebon several incidents had already occurred which Anak Agung does not mention--indeed they were not important within the framework of the negotiations--however, Prof. Schermerhorn mentions them, because they portray the atmosphere between the Dutch and Indonesians very well. The Dutch delegation throughout those negotiations never stayed overnight in Linggajati, as Lord Killearn and his staff did, but rather on the destroyer Blanckart. When the members of the Commission-General were about to land, an incident occurred, a misunderstanding that almost caused an exchange of fire. Our little boat, flying the red-and-white flag, was charged with meeting up with the CommissionGeneral as a courtesy towards foreign guests. However, the crew of the Dutch warship regarded all of Indonesia as still their territory, and did not want to accept the rules, however international their character.

Prof. Schermerhorn in his Diary, p. 109, says: "De stemming van onze marienemansen was beneden nul, en dat een bepaald grondgebied van het Koninkrijk niet zo maar kon worden betreden, deed een van de officieren kennelijk in woede uitbarsten." ("The atmosphere among our seamen was very bad, and the fact that they could not enter a certain part of the Kingdom just like that made one of the officers fly into a rage.") That incident was settled peacefully .

A number of similar incidents occurred. Five such are mentioned in Anak Agung's book (p. 114). Seen through Republican eyes, these incidents were violations committed by the Dutch. But if it was the Republican side that was at fault, then the matter was trumpeted to the skies by the Dutch Press in Jakarta. For 
example, an incident in Tugu station, when the delegation arrived by train in Yogya for the first time. Those leaving Jakarta had no idea that the train would be greeted by a huge multitude of people, and this caused difficulties for the arriving guests. The Dutch side, of course, exploited these incidents in the daily papers they controlled, and, according to Anak Agung: "Several grown boys came up to Abdulkadir Widjojoatmodjo and beat him with sticks." Such an incident absolutely never happened. Supposing that several youths had dared to hit him, according to mass psychology all would have joined in the beating. Shouting obscenities, even spitting was difficult to avoid, but that Abdul Kadir was beaten by several men with sticks, I deny.

Immediately afterwards the Good Offices Committee issued a statement that it was indeed true that extraordinary numbers of people had come to greet them, shouting "merdeka." And it had taken them a long time to get to their car, but not a single person from the Good Offices Committee has lost anything, or experienced ill treatment, such as beating, spitting, and so forth. Thus, the incident was regarded as over, with an apology from the Head of the Delegation and a radio speech by Sri Sultan expressing regret over the incident. The Secretary of the Delegation, who was responsible, was relieved of his position.

\section{A Serious Incident}

One incident that I viewed as serious was the way in which the Dutch delegation sabotaged the Critchley-Du Bois Proposal. All of a sudden the Deputy Head of the Dutch delegation sent a letter to a scheduled [G.O.C.] meeting that, because the C.D. proposal had been leaked, the Dutch delegation was breaking off negotiations and was awaiting fresh instructions from its government. This step was serious. Even though indirectly, the accusation was made that the American delegation had leaked it. In this matter Anak Agung adopts the view of the Dutch side. Kahin in his book, Nationalism and Revolution in Indonesia, has a different opinion. It was not the American Delegation that was responsible for the leak, but the Dutch themselves, via Schorr, an American journalist who was very close to the Dutch (see Kahin, Nationalism and Revolution in Indonesia, p. 249). According to Kahin, "Time did not print Schorr's story covering the contents of the plan. . . . The fact that it had not yet printed Schorr's story when the Dutch broke off negotiations 'in view of the publication of the strictly confidential document . . ' aroused the suspicions of many . . . that the Dutch authorities in Batavia had confidentially leaked this story to Schorr themselves."

On p. 112 Anak Agung writes: "The American government was aware that Du Bois had lost his reputation, and it had to acknowledge that he had exceeded the limits of his charge. This matter was again stressed in the cable report from Van Kleffens to the Minister of Foreign Affairs, relating his discussions with Lovett."

I am not of the opinion that Du Bois was blamed by his Government. Rather, his efforts were appreciated. What Critchley-Du Bois did was not blameworthy, but rather to be praised, because they were attempting to get out of an impasse. This view is in accord with the contents of the cable that was sent by the American Secretary of State Marshall to the Ambassador in The Netherlands, which read as follows: That Du Bois advised the State Department that he had a "serious blood pressure condition which necessitated his early return" to the United States. He stated that he "felt he had contributed all he could to [the] solution" of the DutchIndonesian problem. The Director Far East telegraphed the Consul-General in Jakarta to express the Department's "great concern [over] his condition, very real appreciation [of the] personal sacrifices he had made to [the] ultimate solution [of the] Indonesian problem." Consul-General Livengood was advised of the State 
Department's "particular anxiety that in no circumstances Dubois departure give rise to unfounded speculation that he [was] returning at suggestion or request of [the] Department or on any other grounds save health." (Cable: Marshall to American Ambassador in the Netherlands, June 24, 1948, Foreign Relations of the United States 1948 [Washington: U.S. Government Printing Office, 1974], 6, p. 266.)

This cable went directly from Marshall to the Ambassador in Holland. I think its weight is greater than the cable of Van Kleffens who heard the explanation of Assistant Secretary of State Lovett. The departure of Du Bois was purely for health reasons. Apart from that, Du Bois' replacement, Cochran, who arrived in Jakarta in July, already by August had presented Van Mook with new proposals, the Cochran plan.

Even though inevitably several events are viewed through Dutch spectacles, nevertheless in Anak Agung's dissertation this Indonesian dispute clearly and firmly ends in a way that accords with the ideals of the Indonesian people, that is with the achievement of a free and sovereign Indonesia. That four-year struggle reveals a diplomatic struggle interspersed with war.

In the two military aggressions it appeared as if the story of the Indonesian Republic was finished. In the first military action of July 21, 1947, the Dutch succeeded in occupying a part of Republican territory. In the second action the Dutch succeeded in occupying the Republican Capital. But each time the Dutch met undying opposition from our guerrillas, which prevented them from reestablishing their colonial rule as formerly. Then we saw the action reverse. First, the region of Yogyakarta was returned under the Van Roijen-Roem agreement. Second, all Indonesian territory was returned under the KMB agreement. In this case, we viewed the problem of West Irian as something separate, but in the end Irian fell into Indonesian hands.

\section{Turning-Points}

The prime turning-points in the story as I see it are: The second military action of December 19, 1948. From then on world opinion changed, above all the attitude of America, both in the Committee of Good Offices and in the Security Council. Three times in succession the American representatives received bad treatment. Each time they tried to achieve agreement with a written proposal they were viewed as siding with the Republic, so finally the American Government determined to use the pressure of world opinion and a little economic pressure to force the Dutch into an agreement. The American Government called this a bonafide agreement. From within the Dutch camp too there was pressure; forces that previously had been created to destroy the Republic turned round and supported the Republic. This development was reached on March 3, 1949.

On that day, the BFO, in plenary session, unanimously accepted a resolution that is known as the Anak Agung Resolution, urging, via the High Commissioner of the Crown, that the Netherlands Government fulfill the Republican conditions for participation in a Round Table Conference in order to achieve an accelerated transfer of sovereignty, i.e., by skipping one difficult phase, namely the transitional phase. The Republican Government should be returned to Yogyakarta.

If we again recall the course of the negotiations, then the question of this transitional period was one that, because of the differences of view, it was impossible to solve. According to the Dutch, in this transitional period, the duration of which, in the words of Van Mook, would be long and unspecified, the Republic would not be allowed to have foreign relations, or currency, or its own armed forces. Getting rid of this transitional period was the brilliant concept of Beel, with the purpose of 
constructing an independent (federal) Indonesia consisting of the federal states alone, without the Republic. However, the Security Council Resolution of March 23, 1949 was more brilliant. There was to be no transitional phase, but the Republic would be included directly. Anak Agung's March 3 Resolution made this possible. And from then on, the federalist group followed the same line as the Republic until the conclusion of the KMB. 